\title{
Meningkatkan kemampuan menyimak melalui metode bercerita dengan media gambar pada anak kelompok B di TK Negeri Pembina Bantul
}

\author{
Sarjiyani \\ TK Negeri Pembina Bantul Yogyakarta \\ Jl. Parangtritis Km 8.5 Tembi Timbulharjo Sewon Bantul Yogyakarta Indonesia \\ E-mail: Sarjiyani.yani123@gmail.com
}

\begin{tabular}{|c|c|}
\hline ARTICLE INFO & ABSTRACT \\
\hline $\begin{array}{l}\text { Article history: } \\
\text { Received:28-04-2020 } \\
\text { Revised: } 05-05-2020 \\
\text { Accepted: } 10-05-2020\end{array}$ & $\begin{array}{l}\text { Sebelum anak dapat berbicara dan berkomunikasi dengan baik, anak melakukan } \\
\text { aktivitas menyimak. Penelitian ini bertujuan untuk meningkatkan kemampuan } \\
\text { menyimak melalui metode bercerita dengan media gambar pada anak kelompok B } \\
\text { di TK Negeri Pembina Bantul. Metode penelitian yang digunakan yaitu penelitian } \\
\text { tindakan kelas dengan model Kemmis \& McTaggart. Subjek penelitian ini adalah }\end{array}$ \\
\hline \multirow[t]{2}{*}{$\begin{array}{l}\text { Keywords: } \\
\text { kemampuan menyimak, } \\
\text { metode bercerita, media } \\
\text { gambar, anak }\end{array}$} & $\begin{array}{l}17 \text { anak Kelompok B3 TK Negeri Pembina Bantul yang terdiri dari } 9 \text { anak laki-laki } \\
\text { dan } 8 \text { anak perempuan. Adapun teknik pengumpulan data dilakukan dengan } \\
\text { observasi dan instrumen penelitian berupa pedoman observasi. Kriteria } \\
\text { keberhasilan penelitian ini yaitu } 75 \% \text {. Teknik analisis data menggunakan analisis } \\
\text { data kualitatif dan kuantitatif. Hasil penelitian menunjukkan bahwa kemampuan } \\
\text { menyimak dapat ditingkatkan melalui metode bercerita dengan media gambar. Hal } \\
\text { ini dapat dilihat dari kemampuan anak yang berada pada kriteria Kemampuan anak } \\
\text { yang berada pada kriteria Berkembang Sesuai Harapan (BSH) semula } 4 \text { anak } \\
\text { (23,5\%) pada Siklus I menjadi } 7 \text { anak ( } 41,2 \%) \text { pada Siklus II, artinya mengalami } \\
\text { peningkatan 17,7\%. Kemampuan anak yang berada pada kriteria Berkembang } \\
\text { Sangat Baik (BSB) semula hanya } 1 \text { anak (5,9 \%) pada Siklus I menjadi } 7 \text { anak } \\
(41,2 \%) \text { pada Siklus II, artinya mengalami peningkatan } 35,3 \% \text {. }\end{array}$ \\
\hline & $\begin{array}{l}\text { Before children can talk and communicate well, children listening activities. This } \\
\text { study aims to improve listening skills through the method of storytelling with picture } \\
\text { media in group B children in TK Negeri Pembina Bantul. The research method used } \\
\text { is classroom action research with the Kemmis \& McTaggart model. Subjects were } \\
20 \text { children consisting of } 12 \text { boys and } 8 \text { girls The data collection technique is done } \\
\text { by observation and research instruments in the form of observation guidelines. The } \\
\text { criterion for the success of this study is } 75 \% \text {. Data analysis techniques using } \\
\text { qualitative and quantitative data analysis. The results showed that the ability to listen } \\
\text { could be improved through the method of storytelling with image media. This can be } \\
\text { seen from the ability of children who are in the criteria of Developing in Accordance } \\
\text { with Expectations (BSH) was originally } 4 \text { children (23.5\%) in Cycle I to } 7 \text { children } \\
\text { (41.2\%) in Cycle II, meaning an increase of } 17.7 \% \text {. The ability of children who are } \\
\text { in the criteria of Very Good Development (BSB) was originally only } 1 \text { child (5.9\%) } \\
\text { in Cycle I to } 7 \text { children (41.2\%) in Cycle II, meaning an increase of 35.3\%. }\end{array}$ \\
\hline
\end{tabular}

\section{PENDAHULUAN}

Copyright (C) 2020, Jurnal Pendidikan Anak ISSN 2302-6804 (print), ISSN 2579-4531 (online) 
Jurnal Pendidikan Anak, Volume 9 (1), Tahun 2020

Sarjiyani

Anak usia dini adalah anak yang berusia bayi sejak lahir sampai dengan 6 tahun. Pernyataan ini sesuai dengan Peraturan Menteri Pendidikan dan Kebudayaan RI Nomor 146 Tahun 2014 tentang Kurikulum 2013 Pendidikan Anak Usia Dini, bahwa Pendidikan Anak Usia Dini (PAUD) adalah suatu upaya pembinaan yang ditujukan kepada anak sejak lahir sampai dengan usia 6 tahun yang dilakukan melalui rangsangan pendidikan untuk membantu pertumbuhan dan perkembangan jasmani serta rohani agar anak memiliki kesiapan dalam memasuki pendidikan lebih lanjut. Usia ini disebut sebagai masa emas (golden ages) karena pada masa ini terjadi proses penyambungan sel-sel otak yang menjamin luas dan kokohnya dasar bagi perkembangan selanjutnya. Adapun aspek-aspek yang perlu dikembangkan pada anak usia dini meliputi nilai agama dan moral, fisik motorik, kognitif, bahasa, sosial emosional, dan seni.

Salah satu aspek perkembangan yang perlu distimulasi yaitu perkembangan bahasa. Patmonodewo (2003: p 29) mengemukakan bahwa terdapat dua area pertumbuhan bahasa, yaitu: bahasa yang bersifat pengertian atau reseptif yang meliputi mendengar dan membaca serta bahasa yang bersifat pernyataan atau ekspresif yang meliputi berbicara dan menulis. Untuk menstimulasi anak agar dapat berbicara dan berkomunikasi dengan baik, maka perlu adanya pematangan kemampuan awal sebelum dapat berbicara dan berkomunikasi dengan baik, kemampuan tersebut yaitu kemampuan menyimak. Kemampuan menyimak diperlukan sebagai dasar kemampuan berbicara.

Berdasarkan pengamatan di Taman Kanak-kanak Negeri Pembina Bantul pada kelompok usia 5-6 tahun, ditemukan masalah masih rendahnya kemampuan anak dalam menyimak. Hal ini ditandai dari 17 anak baru 7 anak yang dapat mendengarkan dan memperhatikan saat guru bercerita atau menjelaskan. Sebagian anak memilih bermain sendiri saat mendengarkan cerita, dan sering melihat ke arah lain. Saat dilakukan tanya jawab, sebagian besar anak belum dapat menjawab pertanyaan dan saat mengulang kembali cerita, sebagian besar anak belum mampu menceritakannya kembali. Idealnya untuk usia 5-6 tahun dalam Tingkat Pencapaian Perkembangan anak seperti dalam Peraturan Menteri Pendidikan dan Kebudayaan Republik Indonesia Nomor 137 Tahun 2014 pada lingkup aspek perkembangan Bahasa, anak usia 5-6 tahun mampu menyimak perkataan orang lain dan menceritakan kembali cerita yang pernah didengar. Pembelajaran untuk menstimulasi kemampuan berbicara di TK Negeri Pembina Bantul belum sesuai yang diharapkan. Rendahnya kemampuan berbicara dikarenakan selama ini guru memberikan kegiatan dengan media yang kurang menarik. Dengan demikian, tujuan dalam penelitian ini adalah meningkatkan kemampuan berbicara melalui metode bercerita dengan media gambar.

Untuk mengatasi rendahnya kemampuan menyimak anak, peneliti menggunakan media gambar. Media gambar merupakan suatu gambar yang berkaitan dengan cerita yang berfungsi untuk menyampaikan pesan dari guru kepada anak, sehingga anak akan lebih mudah menerima cerita yang diberikan oleh guru. Media gambar termasuk media visual yang hanya dapat untuk dilihat saja dan tidak memiliki adanya unsur suara atau audio di dalamnya. Media gambar memiliki pengertian lain yang berupa suatu yang diwujudkan dengan bentuk visual atau ke dalam bentuk dua dimensi yang di dalamnya terdapat curahan atau suatu pemikiran dan macam-macamnya seperti lukisan, poster, strip, slide, proyektor dan lainnya.

\section{METODE}

Penelitian ini termasuk jenis penelitian tindakan kelas model Kemmis \& Mc Taggart. Model yang dikemukakan oleh Kemmis \& Mc Taggart (Kusumah dan Dwitagama, 2010: p 21) yaitu terdiri dari empat komponen, yaitu: perencanaan, tindakan, pengamatan dan refleksi. Komponen tersebut merupakan rangkaian dalam satu Siklus dan jumlah Siklus tergantung pada kriteria keberhasilan yang ditargetkan. Adapun skema alur tindakan model Kemmis \& Mc Taggart dapat dilihat pada Gambar 1 berikut ini. 
Jurnal Pendidikan Anak, Volume 9 (1), Tahun 2020

Sarjiyani

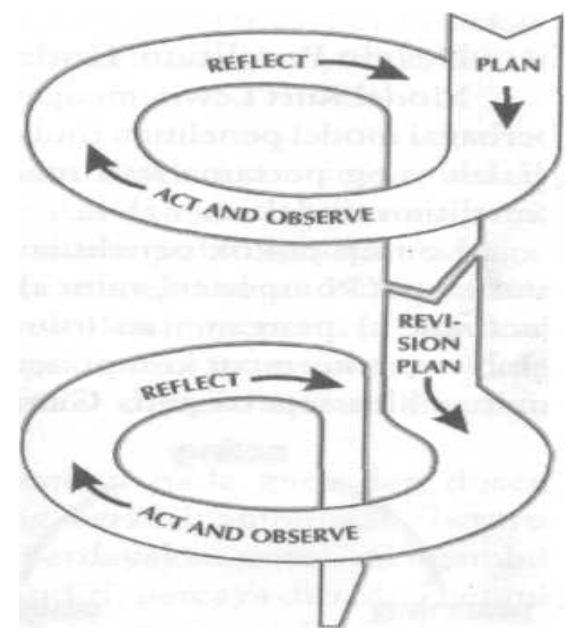

Gambar 1. Siklus PTK Menurut Kemmis \& Mc Taggart

(Kusumah, W. \& Dwitagama, D. 2010: p 21)

Keterangan

1. Plan (Perencanaan)

2. Action (Tindakan)

3. Observe (Pengamatan)

4. Reflect (Refleksi)
5. Revised Plan(Perencanaan revisi)

6. Action II (Tindakan II)

7. Observe II (Pengamatan II)

8. Reflect II (Refleksi II)

Penelitian ini termasuk jenis penelitian tindakan kelas (classroom action research) secara kolaborasi. Suhardjono (2007: p 57) menjelaskan bahwa penelitian tindakan kelas adalah penelitian yang dilakukan oleh guru, bekerja sama dengan peneliti (atau yang di lakukan oleh guru sendiri yang juga bertindak sebagai peneliti) di kelas atau sekolah tempatnya mengajar dan dengan penekanan pada penyempurnaan atau peningkatan proses dan praktis pembelajaran. Dengan demikian adanya kolaborasi dengan pihak terkait merupakan hal yang penting dilakukan agar penelitian tindakan kelas ini dapat berhasil atau tercapai.

Adapun teknik pengumpulan data menggunakan metode observasi dan instrumen penelitian berupa lembar observasi. Dalam lembar observasi disediakan empat alternatif yaitu: Belum Berkembang (BB), Mulai Berkembang (MB), Berkembang Sesuai Harapan (BSH), dan Berkembang Sangat Baik (BSB). Bentuk lembar observasi (pengamatan) dimaksud adalah berbentuk daftar chek dengan memberi tanda chek $(\sqrt{ })$ pada kategori penilaian.

Analisis data yang digunakan pada penelitian ini adalah analisis data deskriptif kuantitatif. Analisis data deskriptif kuantitatif adalah mendeskripsikan dan memaparkan gejala hasil penelitian tanpa bermaksud membuat kesimpulan yang berlaku umum atau generalisasi. Data yang akan dianalisis menggunakan analisis data deskriptif kuantitatif berupa hasil dari pengamatan kemampuan menyimak cerita anak yang terdiri dari tiga aspek. Penghitungan data kuantitatif adalah dengan menghitung ratarata dari keempat aspek kemampuan menyimak cerita anak berdasarkan skor yang diperoleh dari lembar observasi kemampuan menyimak cerita anak. Dari rata-rata yang diperoleh dapat diketahui persentase ketuntasan belajar pada kemampuan menyimak cerita anak. 
Jurnal Pendidikan Anak, Volume 9 (1), Tahun 2020

Sarjiyani

Adapun rumus mean atau rerata nilai menurut Suharsimi Arikunto (2010: p 284-285) yaitu sebagai berikut.

$$
\bar{X}=\frac{\sum X}{N}
$$

Keterangan :

$\bar{X} \quad=$ Mean (rata-rata)

$\sum \mathrm{x}=$ Jumlah nilai

$\mathrm{N}$ = Jumlah yang akan dirata-rata

Rumus untuk menentukan tingkat keberhasilan anak yaitu dengan mempersentase data yang diperoleh yaitu sebagai berikut.

$$
p=\frac{f}{N} \times 100 \%
$$

Keterangan :

$\mathrm{f} \quad=$ frekuensi yang sedang dicari presentasenya

$\mathrm{N} \quad=$ Number of cases (jumlah frekuensi/banyaknya individu seluruhnya)

$\mathrm{p} \quad$ = angka persentase (Sudijono, 2011:p 43)

Analisis data kualitatif dilakukan dengan memberikan deskripsi proses yang dialami selama penelitian tindakan.

Kriteria keberhasilan dalam penelitian ini dinyatakan berhasil apabila hasil nilai rata-rata mencapai $\geq 8,50$ dengan memperlihatkan persentase $75 \%$ dari jumlah anak keseluruhan dapat memenuhi indikator kemampuan menyimak cerita pada kriteria baik. Indikator kemampuan menyimak cerita yang digunakan dalam penelitian ini, yaitu: mengulang kembali cerita secara berurutan ke dalam beberapa kalimat sederhana. Indikator tersebut terdiri dari empat aspek, yaitu: aspek ketepatan, kelancaran dan keberanian.

\section{HASIL DAN PEMBAHASAN}

\section{Hasil}

\section{Pratindakan}

Sebelum melaksanakan penelitian tindakan kelas di kelompok B3 TK Negeri Pembina Bantul, peneliti melakukan pengamatan Pratindakan untuk memperoleh data awal. Data awal yang diperoleh dari Pratindakan akan digunakan untuk mengukur kemampuan menyimak di kelompok B3. Data pengamatan saat Pratindakan yaitu dari 17 anak hanya 4 anak yang mampu menyimak dengan baik.

\section{Siklus I}

1) Perencanaan

Perencanaan tindakan disusun meliputi pembuatan perencanaan pembelajaran berupa Rencana Pelaksanaan Pembelajaran Harian (RPPH), persiapan bahan dan alat untuk kegiatan menyimak dan bercerita pada anak.

2) Pelaksanaan/Tindakan

Pelaksanaan Siklus I pertemuan pertama dilaksanakan pada tanggal 21 Februari 2019 dengan media gambar dengan judul gunung meletus. Adapun langkah-langkahnya yaitu:

a) menyiapkan media gambar.

b) menjelaskan aturan main dalam kelas. 
Jurnal Pendidikan Anak, Volume 9 (1), Tahun 2020

Sarjiyani

c) meminta anak berkumpul dan duduk di karpet menghadap guru.

d) menceritakan dengan media gambar secara utuh sesuai tema yaitu gunung meletus.

e) melakukan tanya jawab seputar cerita. Setiap anak diberi kesempatan untuk menjawab.

f) guru dan anak menyimpulkan isi cerita.

g) guru mengawasi, membimbing, memberi motivasi, dan menilai anak.

Pelaksanaan Siklus I pertemuan dua

Pelaksanaan Siklus I pertemuan kedua dilakukan pada tanggal 25 Februari 2019 dengan media gambar dengan judul gunung meletus. Adapun langkah-langkahnya yaitu:

a) menyiapkan media gambar.

b) menjelaskan aturan main dalam kelas.

c) meminta anak berkumpul dan duduk di karpet menghadap guru.

d) menceritakan dengan media gambar secara utuh sesuai tema yaitu gunung meletus.

e) melakukan tanya jawab seputar cerita. Setiap anak diberi kesempatan untuk menjawab.

f) guru dan anak menyimpulkan isi cerita.

g) guru mengawasi, membimbing, memberi motivasi, dan menilai anak.

3) Pengamatan/Observasi

Berdasarkan hasil pengamatan yang dilakukan anak dalam pembelajaran diketahui bahwa kemampuan menyimak dan bercerita melalui media gambar pada Siklus I berjalan dengan baik. Hal ini tampak pada sebagian besar anak antusias mengikuti pembelajaran dari pada biasanya dan dalam proses pembelajaran tampak adanya peningkatan kemampuan menyimak dan bercerita. Dari 17 anak yang hadir, terdapat 1 anak yang berada pada kriteria Berkembang Sangat Baik (BSB), 4 anak yang berada pada kriteria Berkembang Sesuai Harapan (BSH), 8 anak yang berada pada kriteria Mulai Berkembang (MB), dan 4 anak yang berada pada kriteria Belum Berkembang (BB).

Tabel 1. Penilaian kemampuan menyimak pada siklus I

\begin{tabular}{ccc}
\hline Kriteria & Jumlah anak & Persentase (\%) \\
\hline BB & 4 & $23,5 \%$ \\
\hline MB & 8 & $47,1 \%$ \\
\hline BSH & 4 & $23,5 \%$ \\
\hline BSB & 1 & $5,9 \%$ \\
\hline JUMLAH & 17 & $100 \%$ \\
\hline
\end{tabular}

Berdasarkan Tabel 1 dapat dilihat perhitungan hasil kemampuan menyimak yaitu 1 anak (5,9 \%) berada pada kriteria Berkembang Sangat Baik (BSB), 4 anak (23,5\%) berada pada kriteria Berkembang Sesuai Harapan (BSH), 8 anak $(47,1 \%)$ berada pada kriteria Mulai Berkembang (MB) dan 4 anak berada pada kriteria Belum Berkembang (BB).

4) Refleksi

Sebagian besar anak tampak antusias dalam mengikuti proses pembelajaran, namun demikian kemampuan menyimak dan bercerita anak masih sangat kurang. Hal ini dapat dilihat dari hasil pengamatan bahwa ada 4 anak yang mendapat skor belum berkembang dan 8 anak mendapat skor mulai berkembang. Hal itu dikarenakan anak tidak memiliki konsentrasi yang baik pada saat guru bercerita dengan media gambar, ada anak yang gojek dengan teman sebelahnya. Berdasarkan perhitungan hasil kemampuan menyimak pada Siklus I ternyata hasil belajar belum memenuhi target sebesar 75\%, sehingga penelitian dilanjutkan pada Siklus II. 
Jurnal Pendidikan Anak, Volume 9 (1), Tahun 2020

Sarjiyani

Tabel 2. Simpulan siklus I dan tindak lanjut siklus II

\begin{tabular}{ll}
\hline \multicolumn{1}{c}{ Simpulan Siklus I } & \multicolumn{1}{c}{ Tindak Lanjut Siklus II } \\
\hline $\begin{array}{l}\text { Anak kurang fokus dalam } \\
\text { mendengarkan cerita guru }\end{array}$ & $\begin{array}{l}\text { Mendorong anak agar fokus dalam } \\
\text { mendengarkan cerita guru }\end{array}$ \\
\hline $\begin{array}{l}\text { Anak kurang mampu menceritakan } \\
\text { kembali cerita dari guru }\end{array}$ & $\begin{array}{l}\text { Memotivasi anak agar mampu } \\
\text { menceritakan kembali cerita dari } \\
\text { guru }\end{array}$ \\
\hline $\begin{array}{l}\text { Kurangnya minat anak dalam } \\
\text { menyimak dan bercerita }\end{array}$ & $\begin{array}{l}\text { Mendorong anak agar } \\
\text { bersemangat/berminat dalam } \\
\text { menyimak dan bercerita }\end{array}$ \\
\hline
\end{tabular}

\section{Siklus II}

1) Perencanaan

Perencanaan tindakan disusun meliputi pembuatan perencanaan pembelajaran berupa Rencana Pelaksanaan Pembelajaran Harian (RPPH), persiapan bahan dan alat untuk kegiatan menyimak dan bercerita pada anak. Rencana pelaksanaan pembelajaran terdiri dari dua pertemuan. Pertemuan pertama membahas tema negaraku dengan sub tema kota.

2) Pelaksanaan/Tindakan

Siklus II terdiri dari 2 pertemuan. Pertemuan pertama Siklus II dilaksanakan pada hari Rabu tanggal 6 Maret 2019 melalui kegiatan bercerita dengan judul "Kasuari dan Dara Mahkota". Sedangkan pada pertemuan kedua Siklus II dilaksanakan pada hari Jumat tanggal 8 Maret 2019 melalui kegiatan bercerita dengan judul "Bombi yang Malas".

3) Pengamatan/Obervasi

Berdasarkan hasil pengamatan yang dilakukan atas sikap anak dalam pembelajaran diketahui bahwa kemampuan menyimak dan bercerita pada Siklus II berjalan dengan baik. Terlihat sebagian besar anak antusias mengikuti kegiatan pembelajaran dari pada biasanya, dan dalam proses pembelajaran tampak adanya peningkatan kemampuan menyimak dan bercerita. Anakanak terlihat semangat dan gembira dalam mengikuti proses pembelajaran menyimak dengan media gambar. Apalagi media gambarnya lebih menarik, sehingga membuat anak semakin tertarik mengikuti kegiatan menyimak dan bercerita dengan media gambar. Konsentrasi yang baik sangat membantu anak dalam memahami tugas yang diberikan. Sikap tenang anak dalam menyimak sudah tampak, karena anak sudah terbiasa menyimak guru. Dari 17 anak, terdapat 7 anak yang berada pada kriteria Berkembang Sangat Baik (BSB), 7 anak yang berada pada kriteria Berkembang Sesuai Harapan (BSH), 2 anak yang berada pada kriteria Mulai Berkembang (MB), dan 1 anak yang berada pada kriteria Belum Berkembang (BB).

4) Refleksi

Pada refleksi ini dikemukakan beberapa hal tentang hasil proses pelaksanaan pembelajaran sebagai berikut:

a) Pelaksanaan pembelajaran untuk meningkatkan kemampuan menyimak dan bercerita dengan media gambar pada anak sudah cukup baik.

b) Guru sudah membuat Rencana Pelaksanaan Pembelajaran Harian (RPPH) dengan baik dan dilaksanakan sesuai rencana.

Pada Siklus II, kemampuan menyimak anak telah mencapai 82,4\%. Kemampuan menyimak pada anak kelompok B3 TK Negeri Pembina Bantul menunjukkan peningkatan sebesar 53\%. Dengan demikian dapat disimpulkan bahwa kemampuan menyimak anak sudah mencapai indikator keberhasilan penelitian, sehingga penelitian dihentikan. 
Jurnal Pendidikan Anak, Volume 9 (1), Tahun 2020

Sarjiyani

\section{Perbandingan Siklus I dan Siklus II}

Berdasarkan hasil Siklus I dan II, maka dapat diketahui bahwa pada akhir Siklus terjadi peningkatan pada aspek yang diamati.

Tabel 3. Perkembangan kemampuan menyimak pada siklus I dan siklus II

\begin{tabular}{lcc}
\hline $\begin{array}{c}\text { Perkembangan kemampuan } \\
\text { menyimak dan bercerita }\end{array}$ & Siklus I & Siklus II \\
\hline Belum berkembang & $23 \%$ & $5,8 \%$ \\
\hline Mulai berkembang & $47 \%$ & $11,8 \%$ \\
\hline Berkembang sesuai harapan & $23,5 \%$ & $41,2 \%$ \\
\hline Berkembangsangat baik & $5,9 \%$ & $41,2 \%$ \\
\hline
\end{tabular}

Tabel 3 menjelaskan bahwa kemampuan menyimak di kelompok B3 TK Negeri Pembina Bantul dari Siklus I dan Siklus II yaitu:

Kemampuan anak yang berada pada kriteria Belum Berkembang (BB) yaitu dari 23\% pada Siklus I dan menjadi 5,8 \% pada Siklus II, artinya mengalami penurunan sejumlah 17,2 \%. Kemampuan anak yang berada pada kriteria Mulai Berkembang (MB) semula 8 anak (47\%) pada Siklus I menjadi 2 anak (11,8 \%) pada Siklus II, artinya mengalami penurunan 35,2\%. Kemampuan anak yang berada pada kriteria Berkembang Sesuai Harapan (BSH) semula 4 anak (23,5\%) pada Siklus I menjadi 7 anak $(41,2 \%)$ pada Siklus II, artinya mengalami peningkatan $17,7 \%$. Kemampuan anak yang berada pada kriteria Berkembang Sangat Baik (BSB) semula hanya 1 anak (5,9 \%) pada Siklus I menjadi 7 anak (41,2\%) pada Siklus II, artinya mengalami peningkatan 35,3\%.

\section{Pembahasan}

Hasil penelitian menunjukkan bahwa kemampuan menyimak dapat ditingkatkan melalui metode bercerita dengan media gambar. Menyimak merupakan kegiatan yang penting distimulasi sejak dini. Pernyataan tersebut diperkuat pendapat Bromley dalam Dhieni, N. (2014: p 10.7) bahwa, alasan mengajari anak mendengarkan atau menyimak yaitu: anak dan orang dewasa sebagian besar menghabiskan waktunya untuk mendengar; serta kemampuan mendengarkan sangat penting tidak hanya dalam belajar di kelas, tetapi juga dalam kehidupan sehari-hari. Lebih lanjut Dheni menyatakan bahwa keterampilan menyimak dapat berfungsi sebagai dasar belajar bahasa, menjadi dasar pengembangan kemampuan bahasa tulis, menunjang keterampilan berbahasa lainnya, memperlancar komunikasi lisan dan menambah informasi atau pengetahuan.

Kemampuan menyimak dapat ditingkatkan melalui metode bercerita dengan media gambar. Kegiatan pembelajaran menyimak cerita tersebut dapat menstimulasi anak untuk dapat menyimak secara aktif. Seperti yang dikemukakan oleh Hermawan (2012: p 43-47) menyimak aktif adalah penyimak menunjukkan kepedulian terhadap pembicara, berusaha untuk memahami dan mengingat apa yang didengar dan memberikan tanggapan terhadap apa yang dikatakan pembicara. Kegiatan bercerita dengan media gambar mampu meningkatkan kemampuan menyimak dan bercerita pada anak. Peningkatan tersebut sesuai pendapat Bromley dalam Dhieni, N. (2014: p 4.4) bahwa kemampuan menyimak dipengaruhi oleh faktor penyimak, situasi, dan pembicara.

Kemampuan menyimak penting distimulasi sejak dini karena menyimak memiliki berbagai fungsi. Hal ini sesuai pendapat Tarigan (dalam Dhieni, N., 2014: p 4.16) bahwa, keterampilan menyimak dapat berfungsi untuk: menjadi dasar belajar bahasa, menjadi dasar pengembangan kemampuan bahasa tulis, 
Jurnal Pendidikan Anak, Volume 9 (1), Tahun 2020

Sarjiyani

menunjang keterampilan berbahasa lainnya, memperlancar komunikasi lisan dan menambah informasi atau pengetahuan.

Metode bercerita dipilih untuk meningkatkan kemampuan menyimak karena dapat mengembangkan bahasa dan pikiran anak. Pernyataan tersebut sesuai dengan pendapat Tampubolon (dalam Andi, 2010) bahwa, "bercerita kepada anak memainkan peranan penting bukan saja dalam menumbuhkan minat dan kebiasaan membaca, tetapi juga dalam mengembangkan bahasa dan pikiran anak”. Dengan bercerita pendengaran anak dapat difungsikan dengan baik untuk membantu kemampuan berbicara, dengan menambah perbendaharaan kosa kata, kemampuan mengucapkan kata-kata, melatih merangkai kalimat sesuai tahap perkembangannya, selanjutnya anak dapat mengekspresikannya melalui bernyanyi, bersyair, menulis ataupun menggamar sehingga pada akhirnya anak mampu membaca situasi, gambar, tulisan atau bahasa isyarat. Kemampuan tersebut adalah hasil dari proses menyimak dalam tahap perkembangan bahasa anak. Pendapat tersebut diperkuat Gunarti, W. (2015: p 5.4) bahwa metode bercerita dapat mengembangkan kemampuan bahasa diantaranya kemampuan menyimak dan kemampuan berbicara, mengembangkan kemampuan berpikirnya, menanamkan pesan-pesan moral yang terkandung dalam cerita, mengembangkan kepekaan sosial-emosi anak, melatih daya ingat atau memori anak untuk menerima dan menyimpan informasi melalui tuturan peristiwa yang disampaikan, dan mengembangkan potensi kreatif anak. Selanjutnya gambar dapat membantu anak berpikir konkrit. Hal ini sesuai pendapat Yustina (2017) bahwa media gambar mampu mengatasi keterbatasan pengamatan dan memperjelas gambaran.

\section{SIMPULAN}

Penelitian menunjukkan bahwa kemampuan menyimak dapat ditingkatkan melalui metode bercerita dengan media gambar. Adapun langkah-langkahnya yaitu: anak mendengarkan guru bercerita menggunakan media buku gambar dilanjutkan menjawab pertanyaan mengenai isi cerita. Selain itu, guru juga memberikan reward pada anak yang dapat mengulang kembali cerita dengan tepat, lancar, dan berani. Hasil penelitian menunjukkan bahwa kemampuan menyimak dapat ditingkatkan melalui metode bercerita dengan media gambar. Hal ini dapat dilihat dari kemampuan anak yang berada pada kriteria Kemampuan anak yang berada pada kriteria Berkembang Sesuai Harapan (BSH) semula 4 anak (23,5\%) pada Siklus I menjadi 7 anak (41,2\%) pada Siklus II, artinya mengalami peningkatan 17,7\%. Kemampuan anak yang berada pada kriteria Berkembang Sangat Baik (BSB) semula hanya 1 anak (5,9 \%) pada Siklus I menjadi 7 anak (41,2\%) pada Siklus II, artinya mengalami peningkatan 35,3\%.

\section{UCAPAN TERIMA KASIH}

Terimakasih peneliti ucapkan kepada pembimbing, pihak sekolah dan rekan peneliti yang sangat membantu proses dari awal hingga penyelesaian penelitian ini. Tak lupa peneliti juga mengucapkan terima kasih kepada teman-teman yang saling mendukung dan memberi semangat kepada peneliti. 
Jurnal Pendidikan Anak, Volume 9 (1), Tahun 2020

Sarjiyani

\section{DAFTAR PUSTAKA}

Arikunto, S. (2006). Penelitian tindakan kelas. Jakarta: Bumi Aksara.

Depdikbud. (2003). Undang-undang RI nomor 20 tahun 2003 tentang sistem pendidikan nasional.

Depdikbud. (2014). Permendikbud nomor 146 tahun 2014 tentang kurikulum 2013 PAUD.

Dhieni, N. (2014). Metode pengembangan bahasa. Jakarta: Universitas Terbuka.

Gunarti, W. (2015). Metode pengembangan perilaku dan kemampuan dasar anak usia dini. Jakarta: Universitas Terbuka.

Wardhani, I dan Wihardit, K. (2014). Penelitian tindakan kelas. Jakarta: Universitas Terbuka. 